\title{
Bacterial Stress and Osteoblast Responses on Graphene Oxide-Hydroxyapatite Electrodeposited on Titanium Dioxide Nanotube Arrays
}

\author{
Yardnapar Parcharoen, ${ }^{1}$ Preecha Termsuksawad, ${ }^{2}$ and Sirinrath Sirivisoot ${ }^{3}$ \\ ${ }^{1}$ Chulabhorn International College of Medicine, Thammasat University, Pathum Thani 12120, Thailand \\ ${ }^{2}$ Division of Materials Technology, School of Energy, Environment and Materials, \\ King Mongkut's University of Technology Thonburi, Bangkok 10140, Thailand \\ ${ }^{3}$ Biological Engineering Program, Faculty of Engineering, King Mongkut's University of Technology Thonburi, Bangkok 10140, Thailand
}

Correspondence should be addressed to Sirinrath Sirivisoot; sirinrath.sir@kmutt.ac.th

Received 27 April 2017; Accepted 25 July 2017; Published 30 August 2017

Academic Editor: Faheem Ahmed

Copyright (C) 2017 Yardnapar Parcharoen et al. This is an open access article distributed under the Creative Commons Attribution License, which permits unrestricted use, distribution, and reproduction in any medium, provided the original work is properly cited.

To develop bone implant material with excellent antibacterial and biocompatible properties, nanotubular titanium surface was coated with hydroxyapatite (HA) and graphene oxide (GO). Layer-by-layer deposition was achieved by coating HA on an anodic-grown titanium dioxide nanotube array (ATi) with electrolytic deposition, followed by coating with GO using anodic-electrophoretic deposition. The antibacterial activity against both Gram-negative (Escherichia coli) and Gram-positive (Staphylococcus aureus) bacteria was determined based on the percentage of surviving bacteria and the amount of ribonucleic acid (RNA) leakage and correlated with membrane disruption. The oxidative stress induced in both strains of bacteria by GO was determined by cyclic voltammetry and is discussed. Importantly, the antibacterial GO coatings on HA-ATi were not cytotoxic to preosteoblasts and promoted osteoblast proliferation after 5 days and calcium deposition after 21 days in standard cell culture conditions.

\section{Introduction}

Hydroxyapatite $\left(\mathrm{HA}, \mathrm{Ca}_{10}\left(\mathrm{PO}_{4}\right)_{6}(\mathrm{OH})_{2}\right)$ is a mineralogic component of natural bone with a molar calcium to phosphate ratio of 1.67 [1]. Several methods for coating HA onto biomaterial surfaces include plasma spray, microarc oxidation, and electrodeposition. Electrodeposition is an easy method that allows for adjustment of the thickness and porosity of the HA coating, increased corrosion protection, and reduced release of metal ions by changing systemic parameters. HA may be electrodeposited on an anodic-grown titanium dioxide $\left(\mathrm{TiO}_{2}\right)$ nanotube array on titanium (Ti), which is widely used in orthopedic implants to form a direct bone-to-metal interface, referred to as osseointegration $[2,3]$. $\mathrm{TiO}_{2}$ nanotubes fabricated by anodization are highly ordered and highly adhesive to the substrate due to the intrinsic chemical bonds between the nanotubes and $\mathrm{Ti}$.
Bioactive HA has been widely used as a coating material for dental and orthopedic implants for many years, but by itself, it does not prevent bacterial infection after implantation. Infections associated with surgical implants are generally difficult to be suppressed and may require a longer period of antibiotic therapy and repeated surgical procedures [4]. Antibacterial property of HA coating could be improved by adding other nanomaterials such as graphene oxide.

Graphene oxide (GO) has antibacterial activity that can reduce the risk of bacterial infection. GO nanosheets inhibit bacterial growth $[5,6]$. GO coatings also promote osteoblast function and the antibacterial properties of implant materials $[3,6-8]$. A hydrothermal synthesized nanocomposite of HA nanorods on GO sheets showed faster adsorption of bovine serum albumin in adsorption-desorption process on its surface [9]. Such nanocomposite was suitable for drug delivery due to its biocompatibility, high drug loading efficiency, 
and biodegradability. The nanocomposite of HA on reduced GO was also used as enzymatic electrochemical glucose biosensors which exhibited a superior detection limit and higher sensitivity [10]. Graphene cytotoxicity in neural cells is due to the production of reactive oxygen species (ROS) in a concentration- and time-dependent manner [11,12]. The antibacterial mechanism of another carbon-based nanomaterial, carbon nanotubes (CNTs), is induced by oxidizing a cellular structure or component of bacteria with CNTs [13]. For example, the increased cytotoxicity of single-walled CNTs might be due to an increase of in cellular oxidative stress and a loss of cell membrane integrity [14]. It remains unclear, however, whether intracellular ROS are most likely induced by external ROS produced by GO outside of the bacteria or whether intracellular ROS are directly produced by the GO surface.

Oxidative stress (or ROS formation) generated from other carbon nanomaterials, such as graphene [12], fullerene [15], and CNTs [16], is a key antibacterial mechanism. Many studies have measured oxidative stress and its relationship to disease, such as in acute pancreatitis and hemorrhagic shock syndrome $[17,18]$. In the present study, electrochemical method was used to indirectly detect ROS in bacteria on the electrodeposited GO coatings. Once ROS react with an electron-acceptor protein at the cell membrane, an electrical signal is detected from the bacteria-seeded electrode in an electrochemical cell. Here, oxidative stress in both Gram-positive (Staphylococcus aureus) and Gram-negative (Escherichia coli) bacteria was studied after they colonized on GO coatings after $24 \mathrm{~h}$. In addition, preosteoblast (MC3T3E1) cell proliferation and calcium deposition under standard cell culture condition were examined to determine the early osteoblast response to electrodeposited GO coatings in vitro.

\section{Experimental Materials and Methods}

2.1. Anodic-Electrophoretic Deposition of Graphene. GO solutions were prepared by dispersing GO in isopropyl alcohol (Ajax Finechem, New Zealand) at concentrations of 50, 100, 150, and $200 \mu \mathrm{g} \mathrm{ml}^{-1}$, named GO1, GO2, GO3, and GO4, respectively. GO was deposited by anodic-electrophoretic deposition on HA-ATi samples prepared as described previously $[3,19]$. A direct current of $10 \mathrm{~V}$ was applied at room temperature for $10 \mathrm{~min}$ during anodic-electrophoretic deposition. HA-ATi layers without GO (GO0) were used as a control.

2.2. Physical and Chemical Characterizations. The surface morphology of the coatings was characterized by scanning electron microscopy (SEM, CamScanMX2600, UK) with a $10 \mathrm{keV}$ electron beam. The amount of GO was indirectly analyzed using image analysis software (ImageJ version 1.32, Montgomery, National Institutes of Health, Maryland). The crystal structures of the coating were examined using an Xray diffractometer with $\mathrm{CuK} \alpha 1$ radiation (Shimadzu Model: XRD 6000, Japan) at a scanning rate of $1^{\circ} / \mathrm{min}$.

2.3. Bacterial Responses. All samples were tested against $S$. aureus and E. coli bacteria as Gram-positive and Gramnegative models, respectively. The bacteria were cultured in
Mueller-Hinton broth (Thailand Science Park, Thailand) at $37^{\circ} \mathrm{C}$ for $24 \mathrm{~h}$ with shaking at $200 \mathrm{rpm}$. The bacteria were then centrifuged at $5000 \mathrm{rpm}$ for $5 \mathrm{~min}$. The bacteria pellet was added to $10 \mathrm{ml}$ sterilized saline solution to reach a concentration of bacteria of $10^{6}$ colony forming units (CFU) per milliliter.

2.3.1. Antibacterial Drop Test. Each sample was placed into a sterilized 24 -well plate. Then, $100 \mu \mathrm{l}$ of diluted bacterial suspension was spread on the surface of the sample. After sonication of the sample at $37^{\circ} \mathrm{C}$ for $60 \mathrm{~min}$, the bacteria were washed from the surface of the sample with $1.5 \mathrm{ml}$ sterilized phosphate-buffered saline (PBS) in the sterilized 24 -well plate. Then, $50 \mu \mathrm{l}$ of each bacterial suspension was added to Mueller-Hinton broth and incubated at $37^{\circ} \mathrm{C}$ for $24 \mathrm{~h}$ to measure bacterial absorbance using a spectrophotometer, and percent of relative bacterial cell survival was calculated (1). The reported data are the mean value of three independent experiments.

$$
\begin{aligned}
& \% \text { Relative cell survival } \\
& =\frac{\text { Absorbance of sample } \times 100 \%}{\text { Absorbance of control }} .
\end{aligned}
$$

2.3.2. Measurement of Ribonucleic Acid (RNA) Efflux. First, the media remaining from oxidative stress measurement of each sample were centrifuged at 13,000 rpm for $2 \mathrm{~min}$. The supernatant of the solution was then used to measure the RNA efflux of the bacteria. RNA was separated using a RNA purification kit (RBC Bioscience, Taiwan) in which singlestranded RNA and double-stranded RNA of more than 200 to 1000 of base pairs in length were efficiently purified. Elution solutions of RNA were measured to determine the RNA concentration with a microplate reader (Infinite ${ }^{\circledR} 200$ PRO NanoQuant, Switzerland).

\subsubsection{Determination of Bacterial Oxidative Stress Using the Electrochemical Method}

(1) Preparation of Samples for Electrochemical Measurements. Oxidative stress was studied electrochemically using cyclic voltammetry $(\mathrm{CV})$ technique. $\mathrm{CV}$ analysis was selected as a reliable and effective method to measure oxidative stress without pretreating the sample surface or using any specific chemical before analysis. Effects of various GO concentrations and initial-seeding cell concentrations on oxidative stress in bacterial cells were studied. The oxidation measurement area, $0.25 \mathrm{~cm}^{2}$, was controlled by coating with corrosion-protective paint (Jotun, Thailand), as shown in Figure 1. Prior to testing with bacteria, sterilized samples were exposed to $30,000 \mu \mathrm{WS} \mathrm{cm}{ }^{-2}$ of $254 \mathrm{~nm}$ UV energy (JKL, USA) for $4 \mathrm{~h}$ on each side.

(2) Culture of Bacterial Cells for Electrochemical Measurements. The samples (Figure 1) were placed in a sterilized 24-well plate. Then, $1 \mathrm{ml}$ of the diluted bacterial suspension $\left(10^{6} \mathrm{CFU} \mathrm{ml} \mathrm{m}^{-1}\right)$ was spread onto the sample surface. The bacteria were cultured in Mueller-Hinton broth at $37^{\circ} \mathrm{C}$ for $24 \mathrm{~h}$ at 


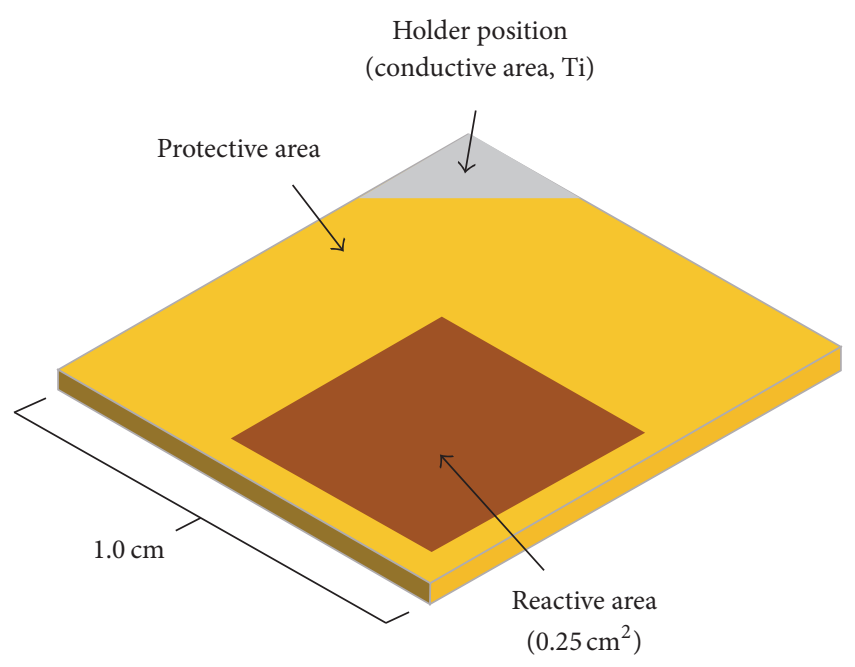

FIGURE 1: Scheme of sample preparation for electrochemical measurements.

an angular velocity of $200 \mathrm{rpm}$. The samples were placed in a three-electrode electrochemical system to measure oxidative stress. Bacteria absorbance in the medium of each sample was measured using a microplate reader (Infinite ${ }^{\circledR} 200$ PRO NanoQuant, Switzerland). Relative bacterial cell survival was calculated using (2). The mean percent of relative cell survival was determined from three independent experiments.

Relative cell survival (\%)

$$
=\frac{\text { Absorbance of sample } \times 100 \%}{\text { Absorbance of control (polystyrene plate) }} .
$$

(3) Cyclic Voltammetry. A three-electrode electrochemical system was used in this study. Samples with living bacteria were used as the working electrodes. A silver/silver chloride (Ag/AgCl, 6.0726.107, Metrohm Autolab B.V., Switzerland) and a platinum coil (Alfa Aesar) were used as reference and counter electrodes, respectively. The changes in the electrical current through working electrodes were recorded with a potentiostat PGSTAT 302N (Metrohm Autolab B.V.) with the NOVA program (version 1.9.16, Metrohm Autolab B.V.). Prior to measurement, all electrodes were cleaned with deionized water. All electrodes were connected to an electrochemical workstation and immersed in electrolyte solution, a 1x PBS (Gibco) solution. CV was also performed in $1.0 \mathrm{mM} \mathrm{K}_{3}\left[\mathrm{Fe}(\mathrm{CN})_{6}\right]$ (Ajax Finechem, New Zealand) dissolved in $0.1 \mathrm{M} \mathrm{NaH}_{2} \mathrm{PO}_{4} / \mathrm{Na}_{2} \mathrm{HPO}_{4}$ (Ajax Finechem, New Zealand) buffer to test for a direct electron transfer at electrodes without living bacteria. The scan rate for $\mathrm{CV}$ was $100 \mathrm{mV} \mathrm{s}^{-1}$, whereas the potential step was $0.00244 \mathrm{~V}$ with a start potential of $-1.0 \mathrm{~V}$. The upper vertex potential, the lower vertex potential, and the stop potential were $+1,-1$, and $-1 \mathrm{~V}$, respectively. Three independent samples were tested for each condition.

\subsection{Osteoblast Responses}

2.4.1. Cell Culture. Preosteoblasts (MC3T3-E, passage number $=11$, Mahidol University, Thailand), were cultured in alpha-modified minimal essential medium (alpha-MEM; Invitrogen Corporation, Paisley, UK) supplemented with 10 vol\% fetal calf serum (Dominique Dutcher, Brumath, France) and $1 \mathrm{vol} \%$ penicillin/streptomycin (Invitrogen Corporation). Cells were cultured at $37^{\circ} \mathrm{C}$ in a humidified atmosphere of $5 \% \mathrm{CO}_{2}$ in air and media were replaced every 3 days.

2.4.2. Cell Viability. Cells were subcultured through trypsinization (0.25\% trypsin and $0.53 \mathrm{M}$ EDTA; Invitrogen Corporation) and then seeded onto plastic polystyrene (control) at a density of $4 \times 10^{4}$ cells cm$~^{-2}$ in 24-well culture plates. Cell viability was tested using a commercial MTT assay (Sigma-Aldrich, Thailand). The $10 \mathrm{vol} \%$ solution of MTT in 1x phosphate buffer saline was mixed with alphaMEM without phenol red to form a yellowish solution before being added to the cell-seeded samples at day 5 of the culture. Mitochondrial dehydrogenases of viable cells cleave the tetrazolium ring, yielding purple formazan crystals on cell-seeded samples after incubation for $1 \mathrm{~h}$. The blue formazan crystals trapped in the cells were dissolved in sterile DMSO $(100 \mu \mathrm{l})$ by incubating at $37^{\circ} \mathrm{C}$ for $30 \mathrm{~min}$. Absorbance of the purple solution was measured at $550 \mathrm{~nm}$ using a spectrophotometer (Synergy Mx Multi-Mode Reader, US). A concomitant change in the amount of formazan formed correlates to the change in the number of viable cells in the samples. Therefore, the percentages of viable cells in the samples are calculated as shown in

$$
\text { Cell viability }(\%)=\frac{\text { Absorbance of colored solution incubated with samples } \times 100 \%}{\text { Absorbance of colored solution incubated with control (polystyrene plate) }}
$$

\subsubsection{Calcium Deposition Assay}

(1) Induction of Osteogenic Differentiation. Preosteoblasts or bone-forming cells were used in this study. The cells were cultured in alpha-MEM (Invitrogen Corporation) supplemented with $10 \mathrm{vol} \%$ fetal calf serum (Dominique Dutcher, Brumath, France), 1 vol\% penicillin/streptomycin (Invitrogen Corporation), $5 \mathrm{mM} \beta$-glycerophosphate (Sigma-Aldrich), $50 \mu \mathrm{g} \mathrm{ml}^{-1}$ ascorbic acid (Sigma-Aldrich), and $100 \mathrm{nM}$ dexamethasone (Sigma-Aldrich) [20]. The initial cell seeding density was 4 $\times 10^{4}$ cells cm$~^{-2}$ at $37^{\circ} \mathrm{C}$ in a humidified atmosphere of $5 \%$ $\mathrm{CO}_{2}$ in air. The cell culture media were replaced every $3 \mathrm{~d}$. The calcium content was monitored at $21 \mathrm{~d}$ of culture.

(2) Cell Lysis and Calcium Content Analysis. After removing the culture media and washing the samples with PBS, $200 \mu \mathrm{l}$ 
SDS lysis buffer was added to each sample. The samples were shaken using an orbital shaker at an angular velocity of $200 \mathrm{rpm}$ for $5 \mathrm{~min}$ and then incubated in a $\mathrm{CO}_{2}$ incubator at $37^{\circ} \mathrm{C}$ for $1 \mathrm{~h}$. Incubated samples were placed into a mixture of $5 \mathrm{~N} \mathrm{HCl}$ solution (Ajax Finechem, New Zealand) and the cell lysate, with a fixed ratio as $250 \mu \mathrm{l}$ of $5 \mathrm{~N} \mathrm{HCl}$ per $1 \mathrm{ml}$ of cell lysate. The solution was mixed with the samples using an orbital shaker at $200 \mathrm{rpm}$ for $5 \mathrm{~min}$. The samples were then incubated at $4^{\circ} \mathrm{C}$ for $4 \mathrm{~h}$.

Calcium quantification was performed after cell lysates were incubated more than $4 \mathrm{~h}$. The cell lysates were then mixed with ethanolamine buffer as $10 \mu \mathrm{l}$ per $1000 \mu \mathrm{l}$ in autoclaved microcentrifuge tubes, and $100 \mu \mathrm{l}$ ortho-cresolphthalein (0.63 mM; Sigma-Aldrich) was added to the ethanolamine and cell lysate solution in microcentrifuge tubes to obtain a purplish red color of solution. The light absorbance of calcium in the supernatant was measured using a microplate reader at a wavelength of $570 \mathrm{~nm}$. The calcium concentration was calculated according to a standard curve generated from a serial dilution of standard calcium solutions. Calcium content was reported as micrograms of calcium per square centimeter of the sample area $\left(\mu \mathrm{g} \mathrm{cm}^{-2}\right)$. Nine samples in each group were tested at culture day 21 . The experiment was repeated three times.

2.5. Statistical Analysis. Analysis of variance (ANOVA) and independent-samples $t$-test were used with Minitab ${ }^{\circledR} 16$ (Minitab Inc., USA). A probability of 0.05 was considered statistically significant.

\section{Results and Discussion}

3.1. Anodic-Electrophoretic Deposition of a Graphene Oxide and Hydroxyapatite Coating. SEM images of GO coatings on HA-ATi by anodic-electrophoretic deposition are shown in Figures 2(a)-2(e). The SEM images show thin layers of GO coatings on top of HA layers. Our previous study confirmed the presence of the carbon content of the GO on the coatings after electrodeposition by energy-dispersive $\mathrm{X}$-ray and Fourier transform infrared spectroscopy [10]. In the present study, quantitative analysis of the carbon content was conducted by indirectly measuring HA intensity using ImageJ. The results in Figure 2 suggest that the HA content decreases when the electrodeposited GO content increases, and the highest GO content was found on the GO4 sample $\left(200 \mu \mathrm{g} \mathrm{ml}^{-1}\right)$ compared to the other coatings. This implies that a thick GO coating is obtained when using a high concentration of GO in the electrolyte during the electrophoretic deposition process. The crystal structures of the samples in the present study were analyzed using $\mathrm{XRD}$, as shown in Figure 3. The results of XRD spectra confirmed that the layers of $\mathrm{HA}\left(\mathrm{Ca}_{10}\left(\mathrm{PO}_{4}\right)_{6}(\mathrm{OH})_{2}\right)$ and $\mathrm{TiO}_{2}$ (anatase phase) existed on all surfaces; however, the intensity of their peaks was lower on the GO-coated samples. In our previous work, XRD spectrum of GO powder (before electrodeposition) showed a peak at two Theta $=10.16^{\circ}[21]$. However, the XRD patterns of GO1, GO2, GO3, and GO4 samples (Figure 3) did not show the peaks at two Theta range of $10-12^{\circ}$. The previous study reported that the absence of the peak at two Theta approximately to $10-12^{\circ}$ was found in reduced GO [22]. It is possible that reduced GO coating is formed after the electrophoretic deposition in the present study. In addition, if GO content in coating is less than $5 \mathrm{wt} \%$, its peak would not show due to limitation of the technique. Although the GO peaks did not appear, it may be implied from XRD patterns that GO existed on the surface due to reduction of apatite and anatase peaks with an increase of GO content used in the anodic-electrophoretic deposition. The reduction of the peaks may be resulted from an increase of GO concentration on the coatings.

\subsection{Bacterial Responses}

3.2.1. Measurements of Bacterial Survival and RNA Leakage. GO0 samples had weak antibacterial activity. The GO-coated samples, however, exhibited considerable antibacterial activity. Specifically, after $1 \mathrm{~h}$ of culture, $98 \%$ (GO1), 49\% (GO2), $34 \%$ (GO2), and $37 \%$ (GO4) of the E. coli survived on the surface of the GO-coated samples. Figure 4 shows similar results for S. aureus. Similar to E. coli, the GO was toxic to $S$. aureus. The GO exhibited stronger antibacterial activities against $S$. aureus than against $E$. coli. In fact, only $86 \%$ (GO1), $57 \%$ (GO2), 23\% (GO3), and 26\% (GO4) of the S. aureus survived on the GO surface after $1 \mathrm{~h}$ of culture. Although electrodeposited GO on HA-ATi was toxic to both types of bacteria, it was more toxic to the Gram-positive (S. aureus) bacteria.

The results confirmed that the GO-coated samples reduced bacterial survival. The mechanisms to kill the bacteria were likely oxidation and membrane disruption. Therefore, the toxicity of the samples to bacteria through membrane damage can be investigated by measuring intracellular materials such as RNA in the supernatant surrounding the bacteria exposed to the GO-coated samples [9]. Thus, the efflux of the cytoplasmic materials of the bacteria was examined by measuring the concentration of RNA in the solution (Figure 4). The RNA concentrations in the solutions of bacteria exposed to GO-coated samples at each concentration were significantly higher than that of the control samples (GO0), except that for GO1 against $E$. coli bacteria. This is due to direct contact between GO and bacteria causing RNA leakage. Because GO has extremely sharp edges, it could damage the bacterial membrane [23]. In the present study, when the GO concentrations increased, RNA leakage also increased.

The RNA effluxes from $S$. aureus exposed to GO were significantly higher than those of $E$. coli under the same culture conditions. This may be due to the greater resistance of $E$. coli in direct contact with the edge of the GO compared with S. aureus. Although S. aureus is a Gram-positive bacteria whose peptidoglycan layer provides additional strength to the cell wall, which is also thicker $(20-80 \mathrm{~nm})$ than that of E. coli (Gram-negative) bacteria $(7-8 \mathrm{~nm})[9,24,25]$, the $S$. aureus was less resistant than E. coli. Gram-negative E. coli has a much thinner layer of peptidoglycan, but it also has a layer of lipopolysaccharides that might protect the cell. A previous report indicated that E. coli exhibited more resistance to direct contact interaction induced by 


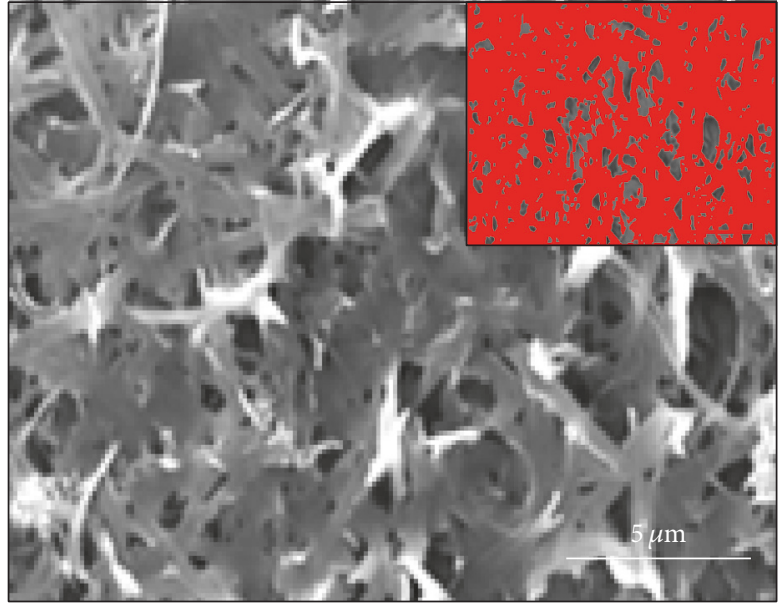

(a)

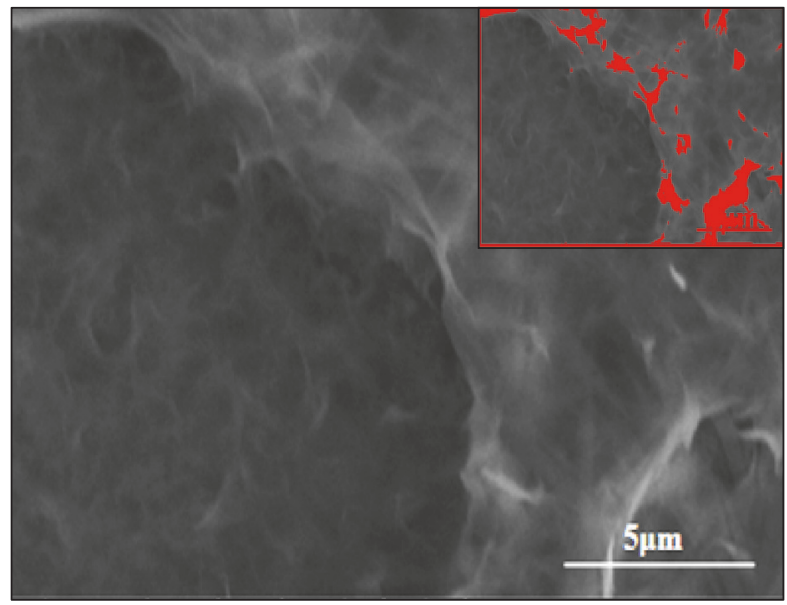

(c)

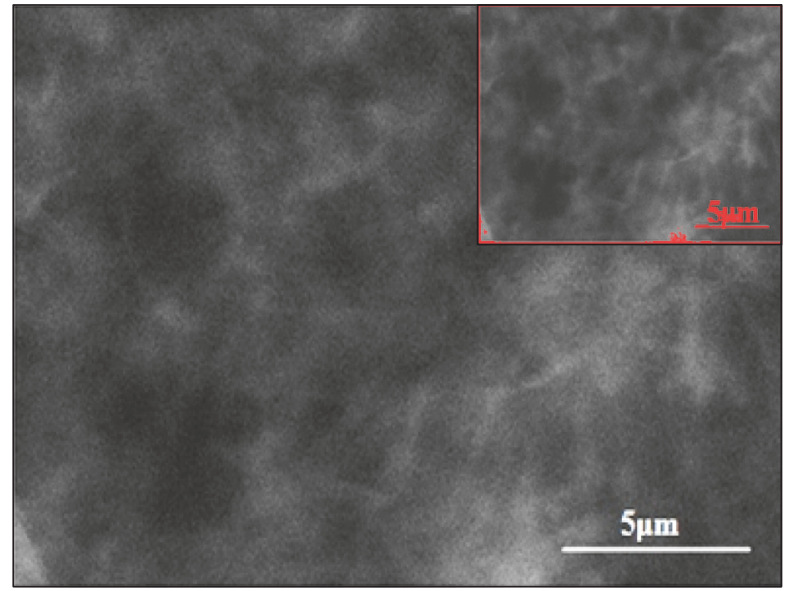

(e)

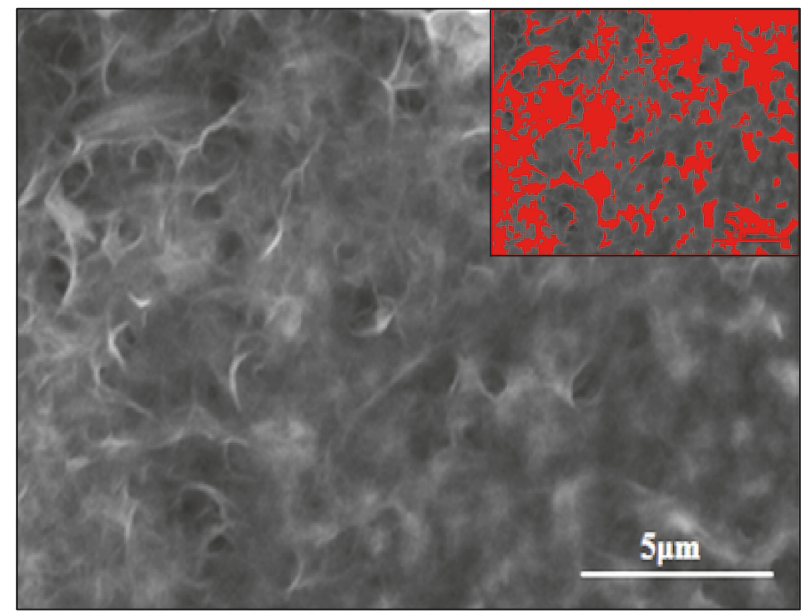

(b)

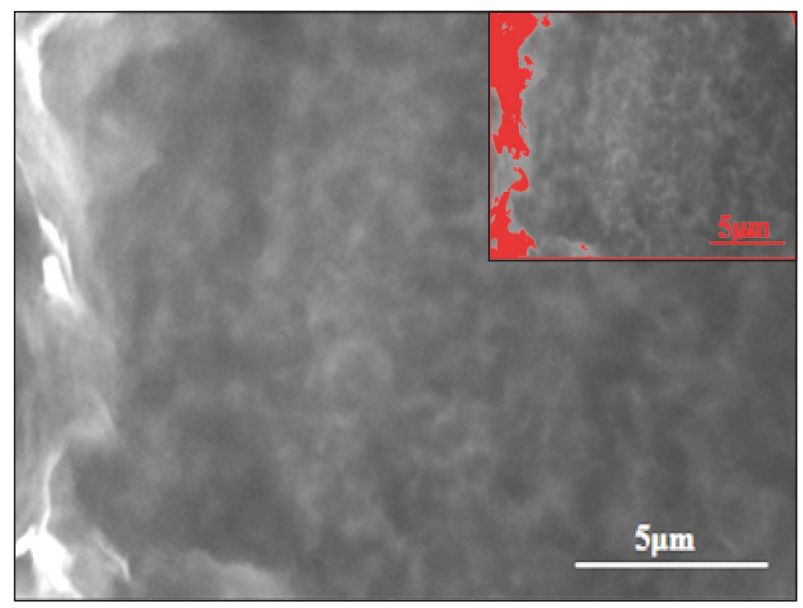

(d)

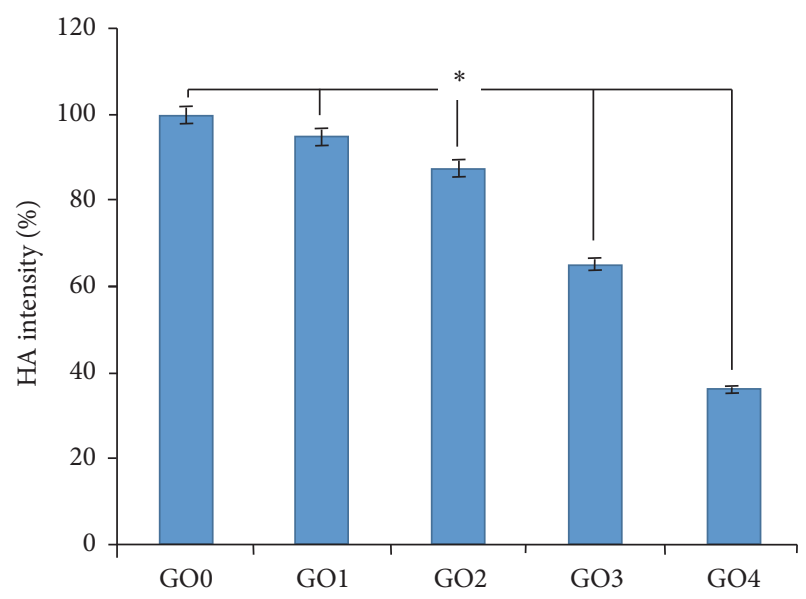

(f)

FIGURE 2: SEM micrographs of GO coated on HA-ATi in a layer-by-layer deposition method on (a) HA-ATi or GO0 and HA-ATi coated with various GO concentrations. (b) GO1; (c) GO2; (d) GO3; (e) GO4. Inset micrographs show ImageJ analysis of the figures; (f) a comparison of HA intensity, derived from ImageJ analysis. The $p$ value was calculated using one-way ANOVA; $N=3,{ }^{*} p<0.05$. Scale bars are $5 \mu$ m. 


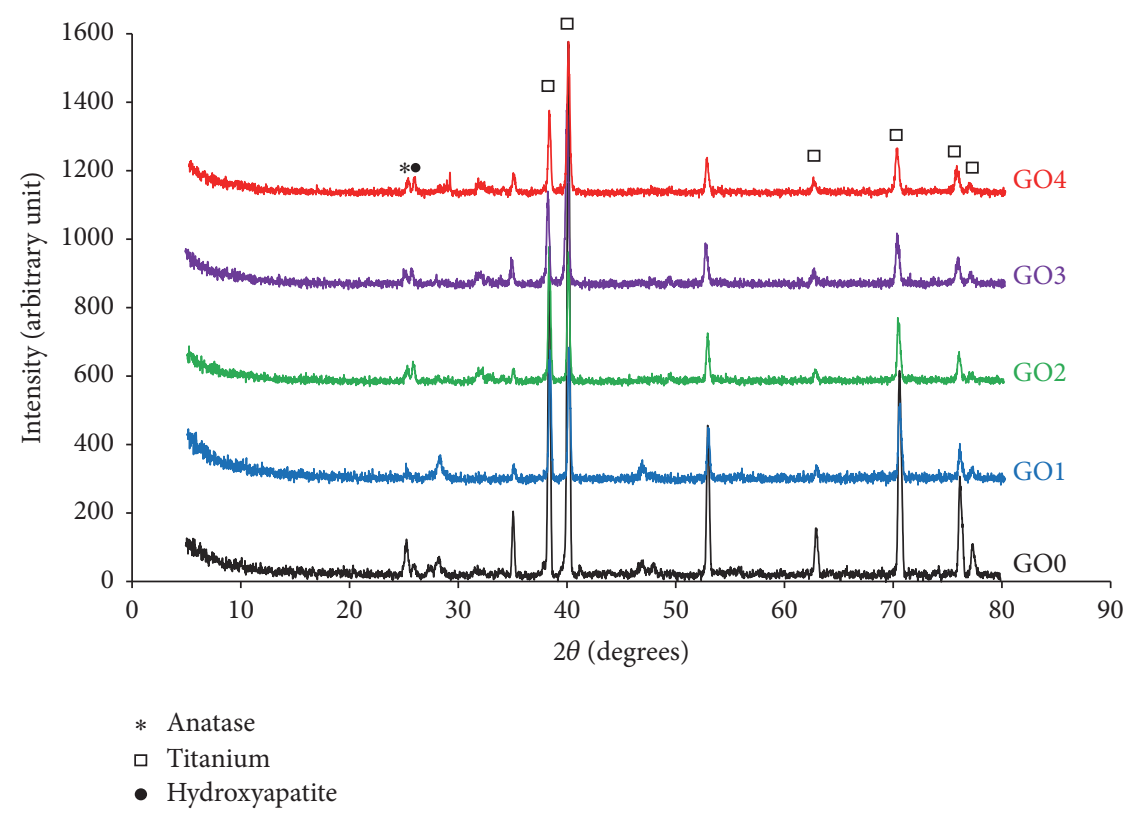

Figure 3: XRD spectra of GO0, GO1, GO2, GO3, and GO4.

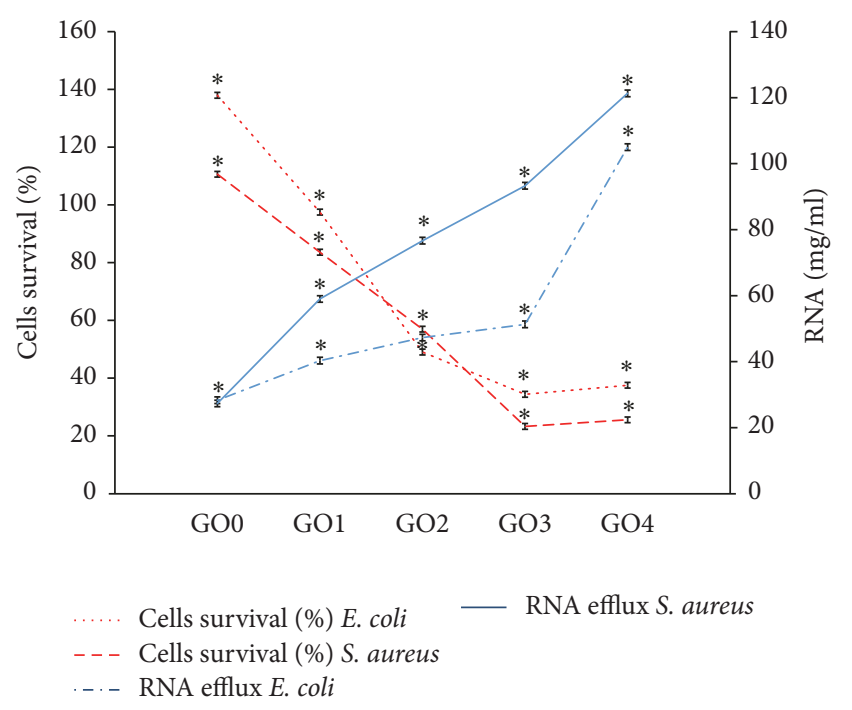

FIgURE 4: Bacterial survival and RNA efflux in PBS after bacteria were cultured on the GO coatings with an antibacterial drop test. The $p$ value was calculated using one-way ANOVA; ${ }^{*} p<0.05$ when compared with other coating conditions.

an atomic force microscopy tip than $S$. aureus due to the outer membrane of the Gram-negative E. coli bacteria [26]. Moreover, comparison between the stiffness of Grampositive and Gram-negative bacterial cells suggested that, for these particular strains of bacteria, the stiffness of $S$. aureus (95 MPa) was lower than that of the E. coli (220 MPa) [27]. Therefore, E. coli should be more resistant to membrane damage than $S$. aureus.

3.2.2. Determination of Bacterial Oxidative Stress Using the Electrochemical Method. Bacterial survival percentages of
S. aureus and E. coli were presented in Figure 5(a). GO0 samples exhibited weak antibacterial activity for both bacteria strains. In contrast, GO-coated samples exhibited considerable antibacterial activity based on a toxicity test. The number of both bacterial species was significantly reduced with an increase in the GO concentration. Relative survival of bacteria on the GO3 sample, however, did not differ significantly from that on the GO4 sample $(p>0.05)$. Antibacterial activities against $S$. aureus of the GO-coated samples were stronger than those against $E$. coli. Importantly, GO on HA-ATi samples was more toxic to Gram-positive S. aureus than Gramnegative $E$. coli. The exact mechanism of damage to the bacteria remains unclear. There are other models, however, suggesting that bacterial adhesion is influenced by some force factors such as electrostatic forces, van der Waals forces, hydrophobic forces, hydrogen bonding, and covalent bonding of bacterial cells and substrates [28, 29]. Mafu et al. reported that the first and the most important such force was the electrostatic force of charges between the surface substrate and bacterial membrane [29]. They show that GO being negatively charged due to the presence of carboxyl, hydroxyl, and epoxy groups is less repulsive to Gram-positive bacteria than Gram-negative bacteria [25].

$\mathrm{CV}$ is fundamental electrochemical method, applied for many electrochemical characterizations. This technique can be used to analyze oxidation/reduction behaviors or antioxidants without requiring any pretreatment, catalysts, or use of specific reagents [30]. CV was used in this study to demonstrate the oxidation signals of both $S$. aureus and E. coli after treatment with different GO concentrations on HA-ATi (Figures 5(b)-5(c). One of the most widely used redox systems utilizes the redox couples of $\mathrm{Fe}(\mathrm{CN})_{6}{ }^{4-/ 3-}$ (Figure 6(a)). The redox couple potentials of $\mathrm{Fe}(\mathrm{CN})_{6}{ }^{4-/ 3-}$ were at $-0.27 /-0.40 \mathrm{~V}_{\mathrm{Ag} / \mathrm{AgCl}}$ for GO-HA-ATi samples. The oxidation peaks at $-0.95 \mathrm{~V}_{\mathrm{Ag} / \mathrm{AgCl}}$ were usually redox couple 


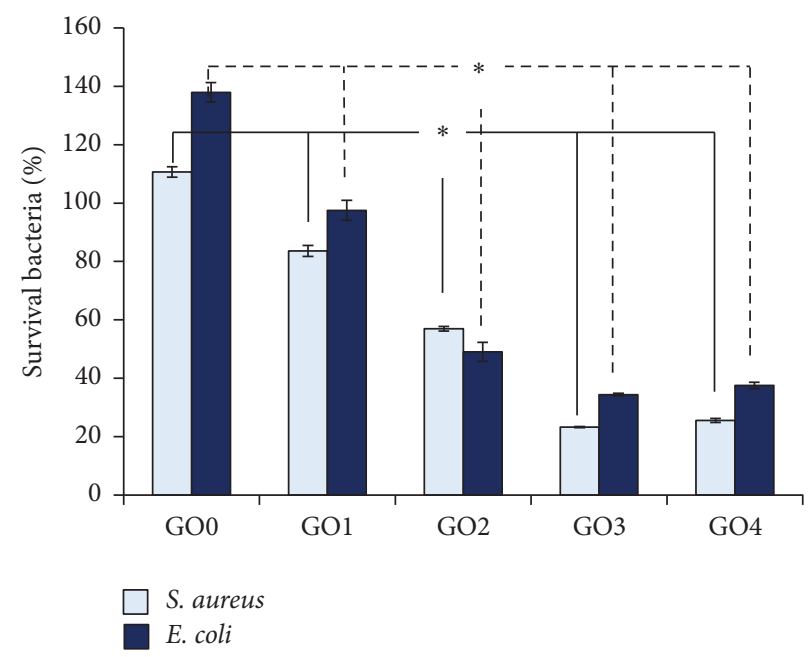

(a)

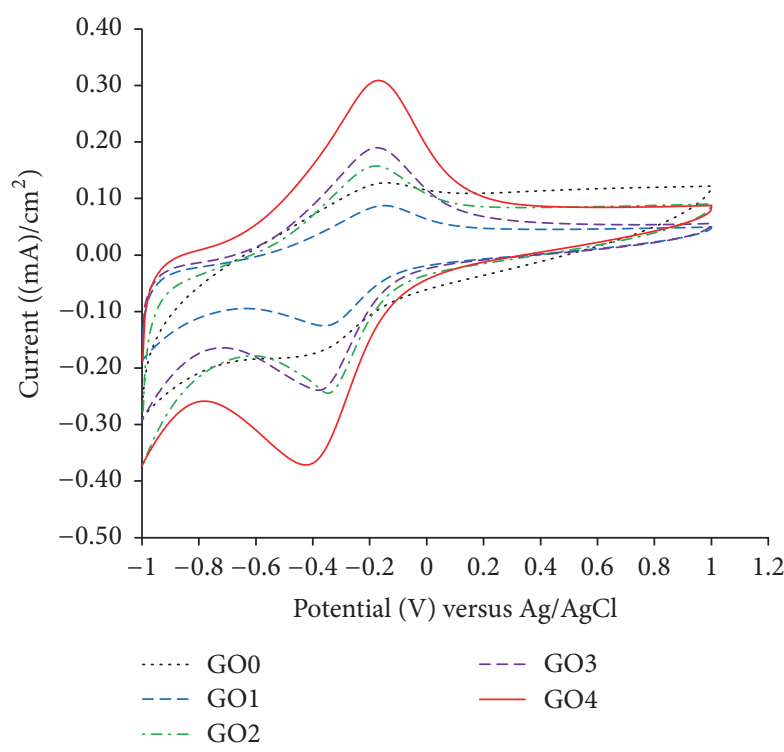

(b)

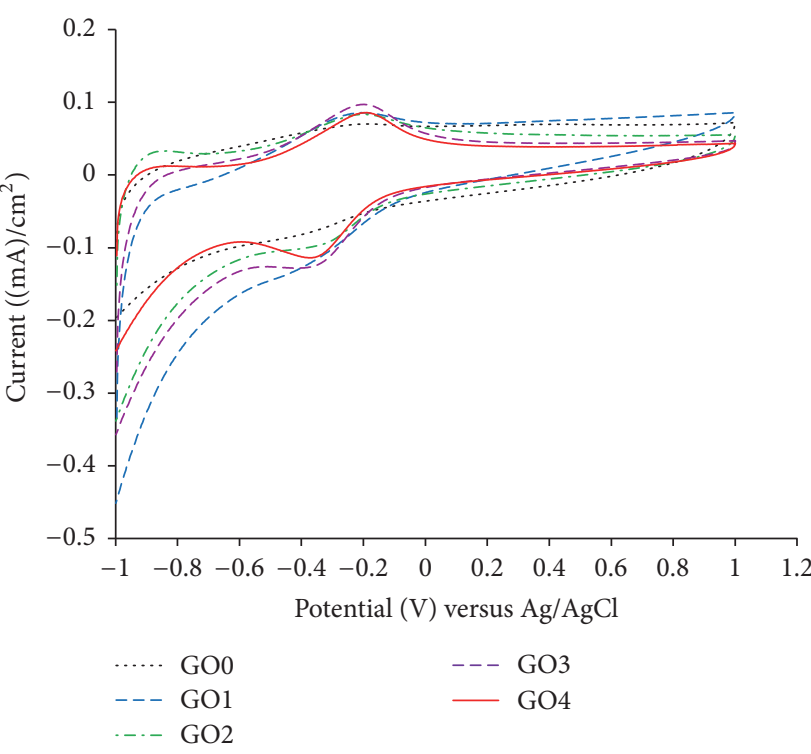

(c)

Figure 5: (a) Cytotoxicity of GO coating on HA-ATi to E. coli and S. aureus exposed to various concentrations of GO coating on HA-ATi samples, for $24 \mathrm{~h}$. The $p$ value was calculated using one-way ANOVA; $N=3 ;{ }^{*} p<0.05$. Cyclic voltammograms of detected (b) $S$. aureus and (c) E. coli ROS. The bacteria were incubated on GO-HA-ATi and CV was measured in PBS electrolyte at room temperature after $24 \mathrm{~h}$.

potentials of $\mathrm{O}_{2} / \mathrm{H}_{2} \mathrm{O}$ [31]. The other controls were samples without an oxidation reaction in PBS solution. There was no oxidation peak but there was a reduction peak, which may be due to the reduction of some of the C-C bonds of GO detected in PBS (Figure 6(b)). Such behavior was previously reported by Kamyabi and Shafiee [32].

The cyclic voltammograms, Figure 5(b), showed the electron exchange of $S$. aureus with the GO coating on HAATi samples. The redox peak was observed in samples with GO coatings. The cyclic voltammograms of GO0, GO1, GO2, GO3, and GO4 in Figure 5(c) showed two pairs of welldefined redox peaks. The oxidation/reduction peaks were at $-0.14 /-0.36$ (GO0), -0.15/-0.32 (GO1), -0.18/-0.33 (GO2),
$-0.18 /-0.36$ (GO3), and $-0.17 /-0.40 \mathrm{~V}_{\mathrm{Ag} / \mathrm{AgCl}}(\mathrm{GO} 4)$. The cyclic voltammograms shown in Figure 5(c) demonstrated the electron exchange of $E$. coli with GO coatings on HAATi samples. A redox peak was observed for all GO coatings except GO0. The cyclic voltammograms of GO1, GO2, GO3, and GO4 in Figure 5(c) showed two pairs of welldefined redox peaks. The oxidation/reduction peaks were at $-0.21 /-0.35$ (GO1), $-0.20 /-0.30$ (GO2), $-0.20 /-0.34$ (GO3), and $-0.19 /-0.33 \mathrm{~V}_{\mathrm{Ag} / \mathrm{AgCl}}(\mathrm{GO} 4)$. The redox peaks demonstrated a shift of the potential for samples incubated with $S$. aureus with various GO concentrations on HA-ATi samples. Qiao et al. reported that the redox peaks resulted from the electron transfer from inside to outside through the cell 


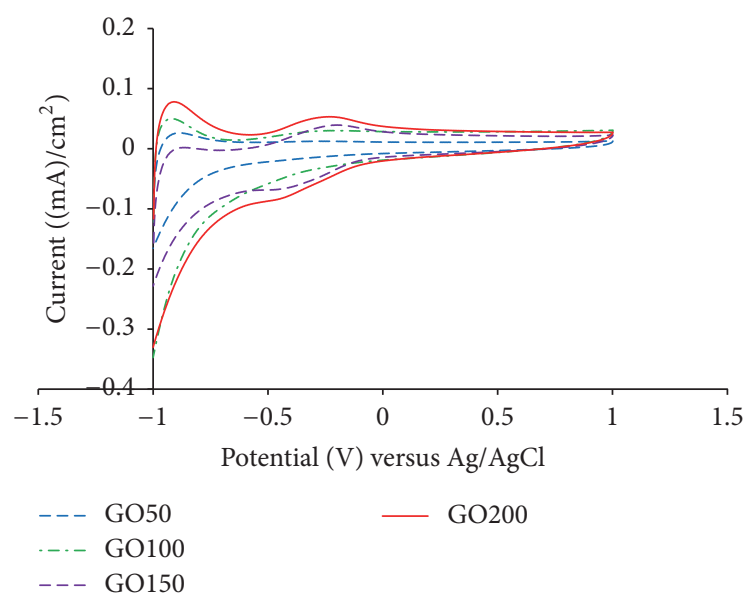

(a)

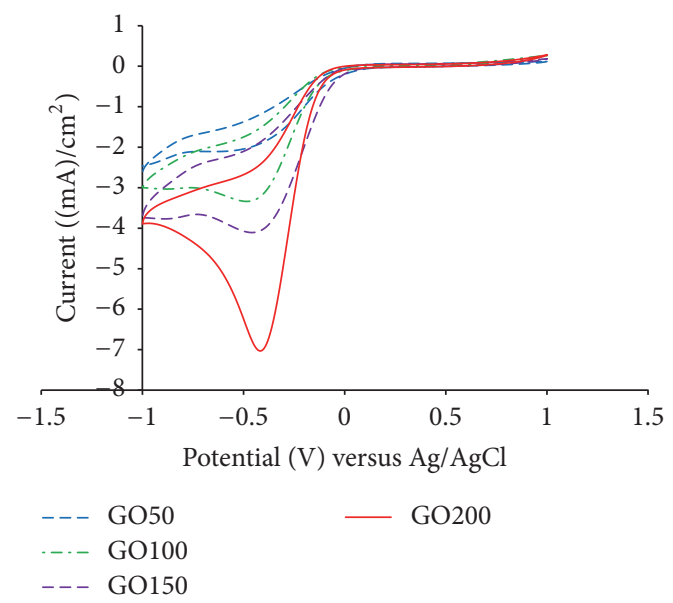

(b)

FIGURE 6: (a) Cyclic voltammograms of the $\mathrm{Fe}(\mathrm{CN})_{6}{ }^{4-/ 3-}$ redox system were used as a positive control and (b) samples without adhered cells in PBS solution were used as a negative control.

membrane using a mediator (outer membrane cytochromes and/or conductive pili) at a voltage of -0.14 to $-0.40 \mathrm{~V}_{\mathrm{Ag} / \mathrm{AgCl}}$ [33].

Furthermore, a shift in the higher oxidation current with an increase in GO concentration was observed (Figures 5(b)$5(c)$ ). For a better understanding of the induced oxidative stress, voltammograms were replotted to compare peak currents, which are representatives of the oxidative power of the materials on each bacterial species, with the GO concentrations (Figure 7). An increase in the GO concentration increased the oxidative current peaks in $S$. aureus, which can be explained in two ways. First, it is possible that a high GO concentration causes high oxidative stress, resulting in high oxidation peak [8]. Second, the increase of GO concentration increased an electrical conduction between bacteria and electrode when GO was used as the mediator of the sensor system [34]. The effect of GO concentration on peak current for E. coli, however, was much lower. As discussed previously, the cell membrane of each bacterium affects adhesion to the substrate. For $S$. aureus, there was a higher potential to adhere on the surface, as shown in the cyclic voltammograms (Figure 7).

To better understand the oxidative stress mechanism, more studies of this bacterial process are needed. Moreover, these GO-coated samples show the potential to be used as sensors to detect biological matter [12]. In situ diagnosis using this GO-coated material will be a new trend for an implantable label-free sensor. Biocompatibility testing will be required to develop this new potential use of this novel material.

\subsection{Osteoblast Responses}

3.3.1. Preosteoblast Proliferation (MTT Assay). To evaluate the biological responses to biomaterials, the osteoblast cell density of $4 \times 10^{4}$ cells $\mathrm{cm}^{-2}$ was seeded on samples in each well. An MTT test was performed to evaluate cell viability. Cell viability was higher in GO3 than in the other samples

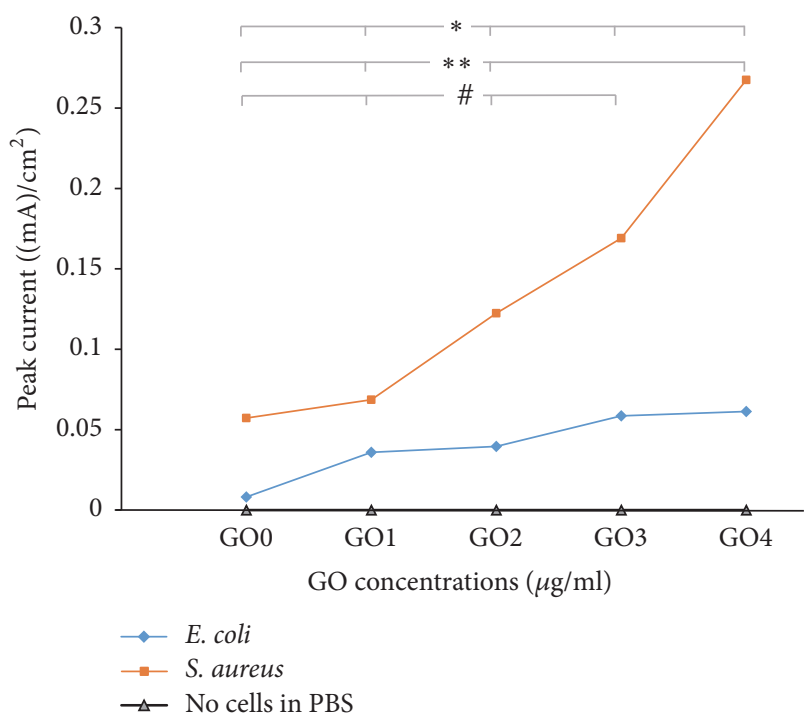

FIgURE 7: Plot of the samples with anodic peak current analysis. A $p$ value was calculated using one-way ANOVA; $N=3 ;^{*} p<0.05$ when compared with coating incubated with $S$. aureus. ${ }^{* * * \#} p<0.05$ when compared with coating incubated with $E$. coli.

(Figure 8). Although MTT activity on HA-ATi (GO0) was high, it was still lower than those on the other GO-coated samples. Thus, the GO did not exert any cytotoxic effects on the cells and actually promoted osteoblast cell attachment and proliferation. Several previous reports focused primarily on the biocompatibility of GO films $[14,35,36]$. The results of the previous studies are generally consistent with those of the present study with regard to the finding that GO film enhances mammalian cell proliferation. Taken together, these findings indicate that GO supports osteoblast growth and proliferation. GO effects on cellular inhibition are dosedependent, as reported by Chang et al. [14]. They found that the GO did not enter A549 (adenocarcinoma human alveolar 


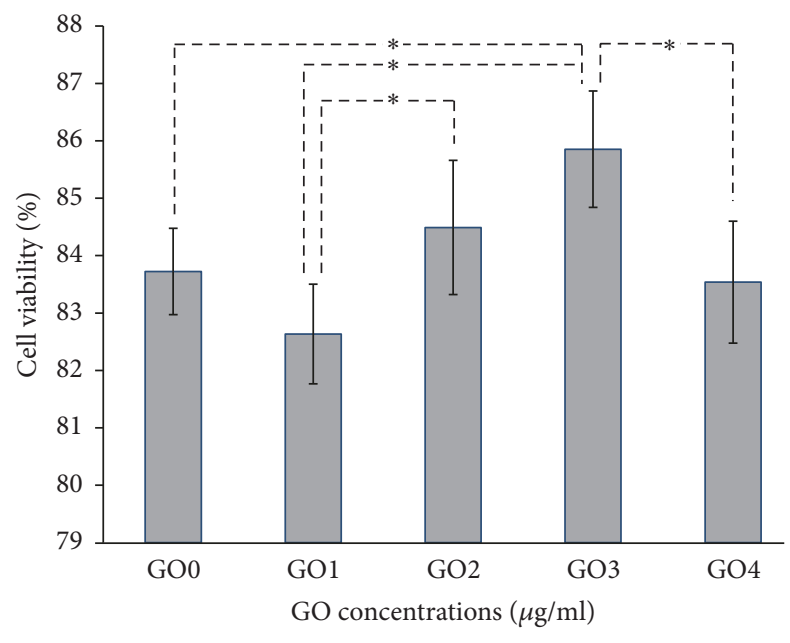

FIgUre 8: MTT test on osteoblast cultures $5 \mathrm{~d}$ after cell seeding. Percentages of cell viability were analyzed using absorbance at $550 \mathrm{~nm}$. The $p$ value was calculated using an independent-samples $t$-test $n=3 ; N=3 ;{ }^{*} p<0.05$.

basal epithelial cells) and had no obvious cytotoxicity. GO causes dose-dependent oxidative stress in the cell and high concentrations of GO induce a slight loss of cell viability. Moreover, Wojtoniszak et al. reported that GO at concentrations ranging from 3.125 to $25 \mu \mathrm{g} \mathrm{ml}^{-1}$ exhibited the best biocompatibility with mouse L929 fibroblast cells [37].

The osteoblast cell membrane has the same negative charge as bacterial cell membranes. The negative charge is due to phosphate groups on the bilayers. The charge of the membrane protein does differs, however, from that of the extracellular matrix. To adhere onto negatively charged surfaces, Gongadze et al. reported that the mechanism was established in two steps [38]. The osteoblast cell membrane first makes nonspecific contact caused by electrostatic forces. Positively charged proteins then attach to the negatively charged surface, followed by specific binding involving an integrin assembly [39]. A number of questions arise regarding the protective mechanism that preosteoblast cells use to protect themselves from GO. Almeida reported that, to prevent oxidative stress, cells utilized diverse mechanisms involving both enzymatic reactions and altered gene transcription [40]. These mechanisms are superior to those of bacteria with respect to stability and high reducing power. In another study, glutathione reductases from Saccharomyces cerevisiae and E. coli were rapidly inactivated following aerobic incubation with $\mathrm{NADPH}, \mathrm{NADH}$, and several reductants in a time- and temperature-dependent manner [41]. Therefore, to eliminate the effect of ROS inside the cells, ROS reduction in mammalian cells must be easier than that in bacteria. The toxicity of GO nanomaterials, however, is concentration dependent for both bacterial and mammalian cells.

3.3.2. Preosteoblast Differentiation (Calcium Deposition). Proliferation of osteoblasts on material surfaces alone, however, is not sufficient to achieve long-term osseointegration for orthopedic implants. For this reason, long-term (in the

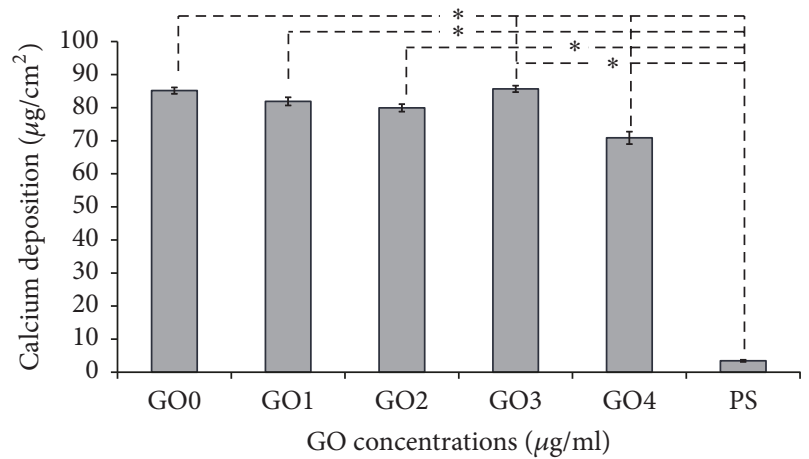

FIGURE 9: Calcium deposition after $21 \mathrm{~d}$ of preosteoblast cultures on the GO coating on HA-ATi and polystyrene surface (PS). The $p$ value was calculated using independent-samples $t$-test; $n=3 ; N=3 ;{ }^{*} p<$ 0.05 .

order of days to weeks) functions of osteoblasts on the GOcoated HA-ATi materials were investigated using a calcium deposition assay. The mineralization process of preosteoblasts in in vitro culture was used as a model to test the effects of biomaterial surfaces on bone cell differentiation and bone formation. Calcium deposition is an indicator of successful in vitro bone formation and can be measured specifically by calcium deposition assay [1].

A calcium deposition assay was performed to evaluate different GO-coated HA-ATi surfaces. For any test period, there were barely detectable amounts of calcium deposited on the polystyrene substrates (Figure 9). The calcium content in the extracellular matrix in all samples in this study was significantly $(p<0.05)$ greater than that on polystyrene substrate formulations after $21 \mathrm{~d}$ of culture. The GO3 surface had the highest ability to support the mineralization of preosteoblast cells after $21 \mathrm{~d}$. Moreover, compared with GO0, the calcium content in the extracellular matrix for GO3 was significantly $(p<0.05)$ greater after culture for $21 \mathrm{~d}$.

The findings of the present study supported previous cell proliferation studies indicating that $\mathrm{GO} 3$ exhibited the highest potential to support cell growth compared with the other concentrations of GO. Proliferation and differentiation showed similar trends. At the beginning, cell-biomaterial interactions during the first period (such as cell adhesion and proliferation) could affect long-term cell function, such as synthesis of extracellular matrix proteins or calcium deposition $[42,43]$.

The effect of GO-coated HA-ATi on bacterial behavior and the response of preosteoblast cells are summarized in Table 1. The cytotoxic effects of the materials on cell survival were classified as medium if cell survival was lower than $70 \%$ according to the ISO 10993-5 standard [44]. In the cases of GO0 and GO1, there was no sign for toxicity toward MC3T3-E1, S. aureus, and E. coli. High GO concentrations (GO2, GO3, and GO4) exhibited slightly toxic effects on both types of bacteria (S. aureus and E. coli.), but not for MC3T3-E1. These findings indicated that biomaterials coated with GO2, GO3, and GO4 had antibacterial properties. Moreover, they were cytocompatible with preosteoblast cells 
TABLE 1: Toxicity of GO-coated sample on MC3T3-E1, S. aureus, and E. coli. (+) indicates cytotoxicity and (-) indicates no harmful effects to the cells.

\begin{tabular}{lcc}
\hline GO concentration on HA-ATi & Organism & Toxicity $(+,-)$ \\
\hline \multirow{2}{*}{$0 \mu \mathrm{g} / \mathrm{ml}$} & MC3T3-E1 & - \\
& S. aureus & - \\
& E. coli & - \\
$50 \mu \mathrm{g} / \mathrm{ml}$ & MC3T3-E1 & - \\
& S. aureus & - \\
& E. coli & - \\
$100 \mu \mathrm{g} / \mathrm{ml}$ & MC3T3-E1 & - \\
& S. aureus & + \\
& E. coli & + \\
$150 \mu \mathrm{g} / \mathrm{ml}$ & MC3T3-E1 & - \\
& S. aureus & + \\
& E. coli & + \\
$200 \mu \mathrm{g} / \mathrm{ml}$ & MC3T3-E1 & - \\
& S. aureus & + \\
& E. coli & + \\
\hline
\end{tabular}

and promoted cell proliferation and calcium deposition. Importantly, the highest cell viability and calcium deposition were observed for GO3. Thus, this novel material has the potential to promote osseointegration of surrounding bone cells. The results of the in vitro study revealed that GOcoated HA-ATi enhanced long-term functions (specifically, concentration of calcium deposition) of preosteoblasts when the GO concentration in electrolyte was $150 \mu \mathrm{g} \mathrm{ml}^{-1}$. More studies of long-term osteoblast cultures are needed to ensure differentiation on GO-HA-ATi.

The cytotoxicity of GO is expected to differ significantly from that of widely studied three-dimensional CNTs [45]. The two materials have a similar crystalline structure, however, but a different shape (flat atomic sheets for GO and tubular for nanotubes). Zhang et al. studied GO interactions with neuron-like cells (PC12) in vitro and found that GO cytotoxicity in PC12 cells was relatively low compared with CNT; both GO and CNT induced concentration- and shapedependent cytotoxic effects [11]. Zhang et al. [11] also suggested that fibroblast adhesion and proliferation should be studied in addition to preosteoblasts to examine the integration between implants with the surrounding soft tissues. Moreover, the solubility of GO composite in stimulated body fluid solution should be tested to confirm the stability of this composite material in the host [46].

\section{Conclusions}

The antibacterial properties and osteoblast response (proliferation and calcium deposition) of GO on HA-ATi samples were studied. The GO coatings on HA-ATi were prepared using anodic-electrophoretic deposition. Various GO concentrations in electrolytes were used to deposit GO nanowalls on HA-ATi. Based on the antibacterial drop test, GO reduced the growth of bacteria in both strain models: $S$. aureus and E. coli. The results of RNA leakage tests revealed that direct contact of the bacteria with GO causes membrane stress, leading to irreversible damage. The RNA efflux indicated greater damage to the cell membrane of $S$. aureus compared with the cell membrane of $E$. coli. The higher resistance of $E$. coli against interaction with the nanowalls compared with $S$. aureus might be due to the greater stiffness of $E$. coli. The increased current density of oxidative peaks in the CV tests in this study positively correlated with the number of surviving bacteria, suggesting that the increase in cytotoxicity was due to an increase in cellular oxidative stress (similar to the result of membrane stress causing RNA leakage). Therefore, the findings of the present study indicated that survival of bacteria, oxidative stress, and membrane stress were GO-concentration-dependent mechanisms. The results also suggested that GO-HA composite coatings decreased susceptibility to both $S$. aureus and E. coli and thus could be applied as effective antibacterial agents to suppress bacterial invasion in orthopedic implants. Moreover, the osteoblast responses demonstrated that the GO-HA composite coatings increased osteoblast proliferation after $5 \mathrm{~d}$ of cultures. The results from the calcium deposition assay after culture for $21 \mathrm{~d}$ confirmed that GO-HA composite coatings supported an early stage of osteoblast differentiation. Electrodeposited GO at concentrations of $150 \mu \mathrm{g} \mathrm{ml}^{-1}$ and $200 \mu \mathrm{g} \mathrm{ml}^{-1}$ was found to be optimal in this study because GO coatings at these concentrations induced cell death in both strains of bacteria but promoted high proliferation and calcium deposition of preosteoblasts. Therefore, GO electrodeposited on HA-ATi are very promising not only for antibacterial applications, but also for orthopedic applications. Further in vitro studies and in vivo studies are needed to examine long-term osteoblast differentiation, protein, and gene expression of osteoblasts.

\section{Conflicts of Interest}

The authors declare that there are no conflicts of interest regarding the publication of this article.

\section{Acknowledgments}

The authors would like to acknowledge the Research Strengthening Project of the Faulty of Engineering, King Mongkut's University of Technology Thonburi, Bangkok, Thailand, for funding.

\section{References}

[1] M. S.-A. Johnsson and G. H. Nancollas, "The role of Brushite and octacalcium phosphate in apatite formation," Critical Reviews in Oral Biology and Medicine, vol. 3, no. 1-2, pp. 61-82, 1992.

[2] K. S. Brammer, S. Oh, C. J. Cobb, L. M. Bjursten, H. van der Heyde, and S. Jin, "Improved bone-forming functionality on diameter-controlled $\mathrm{TiO}_{2}$ nanotube surface," Acta Biomaterialia, vol. 5, no. 8, pp. 3215-3223, 2009.

[3] Y. Parcharoen, P. Kajitvichyanukul, S. Sirivisoot, and P. Termsuksawad, "Hydroxyapatite electrodeposition on anodized titanium nanotubes for orthopedic applications," Applied Surface Science, vol. 311, pp. 54-61, 2014. 
[4] J. D. Whitehouse, N. Deborah Friedman, K. B. Kirkland, W. J. Richardson, and D. J. Sexton, "The impact of surgicalsite infections following orthopedic surgery at a community hospital and a university hospital: adverse quality of life, excess length of stay, and extra cost," Infection Control and Hospital Epidemiology, vol. 23, no. 4, pp. 183-189, 2002.

[5] K. Krishnamoorthy, U. Navaneethaiyer, R. Mohan, J. Lee, and S. Kim, "Graphene oxide nanostructures modified multifunctional cotton fabrics," Applied Nanoscience, vol. 2, no. 2, pp. 119126, 2012.

[6] S. Liu, T. H. Zeng, M. Hofmann et al., "Antibacterial activity of graphite, graphite oxide, graphene oxide, and reduced graphene oxide: membrane and oxidative stress," ACS Nano, vol. 5, no. 9, pp. 6971-6980, 2011.

[7] O. Akhavan and E. Ghaderi, "Toxicity of graphene and graphene oxide nanowalls against bacteria," ACS Nano, vol. 4, no. 10, pp. 5731-5736, 2010.

[8] Y. Parcharoen, P. Termsuksawad, and S. Sirivisoot, "Electrochemical deposition of novel graphene oxide-hydroxyapatite composite onto titanium dioxide nanotubes for orthopaedic applications," in International Conference on Advances in Science and Technology (ICAST), pp. 201-208, Science Publication, Pattaya, Thailand, 2014.

[9] G. Bharath, B. S. Latha, E. H. Alsharaeh, P. Prakash, and N. Ponpandian, "Enhanced hydroxyapatite nanorods formation on graphene oxide nanocomposite as a potential candidate for protein adsorption, $\mathrm{pH}$ controlled release and an effective drug delivery platform for cancer therapy," Analytical Methods, vol. 9, no. 2, pp. 240-252, 2017.

[10] G. Bharath, R. Madhu, S.-M. Chen et al., "Enzymatic electrochemical glucose biosensors by mesoporous $1 \mathrm{D}$ hydroxyapatiteon-2D reduced graphene oxide," Journal of Materials Chemistry B, vol. 3, no. 7, pp. 1360-1370, 2015.

[11] Y. Zhang, S. F. Ali, E. Dervishi et al., "Cytotoxicity effects of graphene and single-wall carbon nanotubes in neural phaeochromocytoma-derived pc12 cells," ACS Nano, vol. 4, no. 6, pp. 3181-3186, 2010.

[12] J. Li, L. Zheng, L. Zeng, Y. Zhang, L. Jiang, and J. Song, “RGD Peptide-Grafted Graphene Oxide as a New Biomimetic Nanointerface for Impedance-Monitoring Cell Behaviors," Journal of Nanomaterials, vol. 2016, Article ID 2828512, 2016.

[13] C. D. Vecitis, K. R. Zodrow, S. Kang, and M. Elimelech, "Electronic-structure-dependent bacterial cytotoxicity of single-walled carbon nanotubes," ACS Nano, vol. 4, no. 9, pp. 5471-5479, 2010.

[14] Y. Chang, S. T. Yang, J. H. Liu et al., "In vitro toxicity evaluation of graphene oxide on A549 cells," Toxicology Letters, vol. 200, pp. 201-210, 2011.

[15] D. Y. Lyon, L. Brunet, G. W. Hinkal, M. R. Wiesner, and P. J. J. Alvarez, "Antibacterial activity of fullerene water suspensions (nC 60) is not due to ROS-mediated damage," Nano Letters, vol. 8, no. 5, pp. 1539-1543, 2008.

[16] S. Kang, M. Herzberg, D. F. Rodrigues, and M. Elimelech, "Antibacterial effects of carbon nanotubes: size does matter!," Langmuir, vol. 24, no. 13, pp. 6409-6413, 2008.

[17] A. Mittal, R. J. Flint, M. Fanous et al., "Redox status of acute pancreatitis as measured by cyclic voltammetry: Initial rodent studies to assess disease severity," Critical Care Medicine, vol. 36, no. 3, pp. 866-872, 2008.

[18] A. Mittal, F. Göke, R. Flint et al., "The redox status of experimental hemorrhagic shock as measured by cyclic voltammetry," Shock, vol. 33, no. 5, pp. 460-466, 2010.
[19] A. Mohammed Ali Al-Sammarraie and M. Hasan Raheema, "Electrodeposited Reduced Graphene Oxide Films on Stainless Steel, Copper, and Aluminum for Corrosion Protection Enhancement," International Journal of Corrosion, vol. 2017, pp. $1-8,2017$.

[20] P. Arpornmaeklong, S. E. Brown, Z. Wang, and P. H. Krebsbach, "Phenotypic characterization, osteoblastic differentiation, and bone regeneration capacity of human embryonic stem cellverived mesenchymal stem cells," Stem Cells and Development, vol. 18, no. 7, pp. 955-968, 2009.

[21] P. Tanurat and S. Sirivisoot, "Osteoblast proliferation on graphene oxide eletrodeposited on anodized titanium," in Proceedings of the 8th Biomedical Engineering International Conference, BMEiCON 2015, tha, November 2015.

[22] K. Satheesh and R. Jayavel, "Synthesis and electrochemical properties of reduced graphene oxide via chemical reduction using thiourea as a reducing agent," Materials Letters, vol. 113, pp. 5-8, 2013.

[23] X. Guo and N. Mei, "Assessment of the toxic potential of graphene family nanomaterials," Journal of Food and Drug Analysis, vol. 22, no. 1, pp. 105-115, 2014.

[24] M. T. Cabeen and C. Jacobs-Wagner, "Bacterial cell shape," Nature Reviews Microbiology, vol. 3, no. 8, pp. 601-610, 2005.

[25] B. Gottenbos, D. W. Grijpma, H. C. Van Der Mei, J. Feijen, and H. J. Busscher, "Antimicrobial effects of positively charged surfaces on adhering Gram-positive and Gram-negative bacteria," Journal of Antimicrobial Chemotherapy, vol. 48, no. 1, pp. 7-13, 2001.

[26] Y. F. Dufrene, "Refining our perception of bacterial surfaces with the atomic force microscope," Journal of Bacteriology, vol. 186, no. 11, pp. 3283-3285, 2004.

[27] P. Eaton, J. C. Fernandes, E. Pereira, M. E. Pintado, and F. Xavier Malcata, "Atomic force microscopy study of the antibacterial effects of chitosans on Escherichia coli and Staphylococcus aureus," Ultramicroscopy, vol. 108, no. 10, pp. 1128-1134, 2008.

[28] J. Li and L. A. McLandsborough, "The effects of the surface charge and hydrophobicity of Escherichia coli on its adhesion to beef muscle," International Journal of Food Microbiology, vol. 53, no. 2-3, pp. 185-193, 1999.

[29] A. A. Mafu, C. Plumety, L. Deschênes, and J. Goulet, "Adhesion of pathogenic bacteria to food contact surfaces: Influence of $\mathrm{pH}$ of culture," International Journal of Microbiology, Article ID 972494, 2011.

[30] J. F. Arteaga, M. Ruiz-Montoya, A. Palma, G. Alonso-Garrido, S. Pintado, and J. M. Rodríguez-Mellad, "Comparison of the simple cyclic voltammetry (CV) and DPPH assays for the determination of antioxidant capacity of active principles," Molecules, vol. 17, no. 5, pp. 5126-5138, 2012.

[31] G. Tratnyek Paul, in Aquatic Redox Chemistry, Grundl Timothy and B. Haderlein Stefan, Eds., American Chemical Society, 2011.

[32] M. A. Kamyabi and M. A. Shafiee, "Electrocatalytic oxidation of dopamine, ascorbic acid and uric acid at poly-2,6-diaminopyridine on the surface of carbon nanotubes/GC electrodes," Journal of the Brazilian Chemical Society, vol. 23, no. 4, pp. 593-601, 2012.

[33] Y. Qiao, C. M. Li, S.-J. Bao, Z. Lu, and Y. Hong, "Direct electrochemistry and electrocatalytic mechanism of evolved Escherichia coli cells in microbial fuel cells," Chemical Communications, no. 11, pp. 1290-1292, 2008.

[34] F. Liu, K. S. Choi, T. J. Park, S. Y. Lee, and T. S. Seo, “Graphenebased electrochemical biosensor for pathogenic virus detection," Biochip Journal, vol. 5, no. 2, pp. 123-128, 2011. 
[35] H. Chen, M. B. Müller, K. J. Gilmore, G. G. Wallace, and D. Li, "Mechanically strong, electrically conductive, and biocompatible graphene paper," Advanced Materials, vol. 20, no. 18, pp. 3557-3561, 2008.

[36] S. Park, N. Mohanty, J. W. Suk et al., "Biocompatible, robust freestanding paper composed of a TWEEN/graphene composite," Advanced Materials, vol. 22, no. 15, pp. 1736-1740, 2010.

[37] M. Wojtoniszak, X. Chen, R. J. Kalenczuk et al., "Synthesis, dispersion, and cytocompatibility of graphene oxide and reduced graphene oxide," Colloids and Surfaces B: Biointerfaces, vol. 89, no. 1, pp. 79-85, 2012.

[38] E. Gongadze, D. Kabaso, S. Bauer, J. Park, P. Schmuki, and A. Iglič, "Adhesion of osteoblasts to a vertically aligned $\mathrm{TiO} 2$ nanotube surface," Mini-Reviews in Medicinal Chemistry, vol. 13, no. 2, pp. 194-200, 2013.

[39] G. Ekaterina, K. Doron, B. Sebastian et al., "Adhesion of osteoblasts to a nanorough titanium implant surface," International Journal of Nanomedicine, vol. 6, 1816 pages, 2011.

[40] M. Almeida, "Aging mechanisms in bone," BoneKEy Reports, vol. 1, no. 7, 2012.

[41] M. C. Pinto, A. M. Mata, and J. Lopez-barea, "Reversible inactivation of Saccharomyces cerevisiae glutathione reductase under reducing conditions," Archives of Biochemistry and Biophysics, vol. 228, no. 1, pp. 1-12, 1984.

[42] J. Y. Martin, Z. Schwartz, T. W. Hummert et al., "Effect of titanium surface roughness on proliferation, differentiation, and protein synthesis of human osteoblast-like cells (MG63)," Journal of Biomedical Materials Research, vol. 29, no. 3, pp. 389-401, 1995.

[43] B. Groessner-Schreiber and R. S. Tuan, "Enhanced extracellular matrix production and mineralization by osteoblasts cultured on titanium surfaces in vitro," Journal of Cell Science, vol. 101, no. 1, pp. 209-217, 1992.

[44] J. C. Hornez, A. Lefèvre, D. Joly, and H. F. Hildebrand, "Multiple parameter cytotoxicity index on dental alloys and pure metals," Biomolecular Engineering, vol. 19, no. 2-6, pp. 103-117, 2002.

[45] V. L. Colvin, "The potential environmental impact of engineered nanomaterials," Nature Biotechnology, vol. 21, no. 10, pp. 1166-1170, 2003.

[46] C. Zhao, X. Lu, C. Zanden, and J. Liu, "The promising application of graphene oxide as coating materials in orthopedic implants: Preparation, characterization and cell behavior," Biomedical Materials (Bristol), vol. 10, no. 1, Article ID 015019, 2015. 

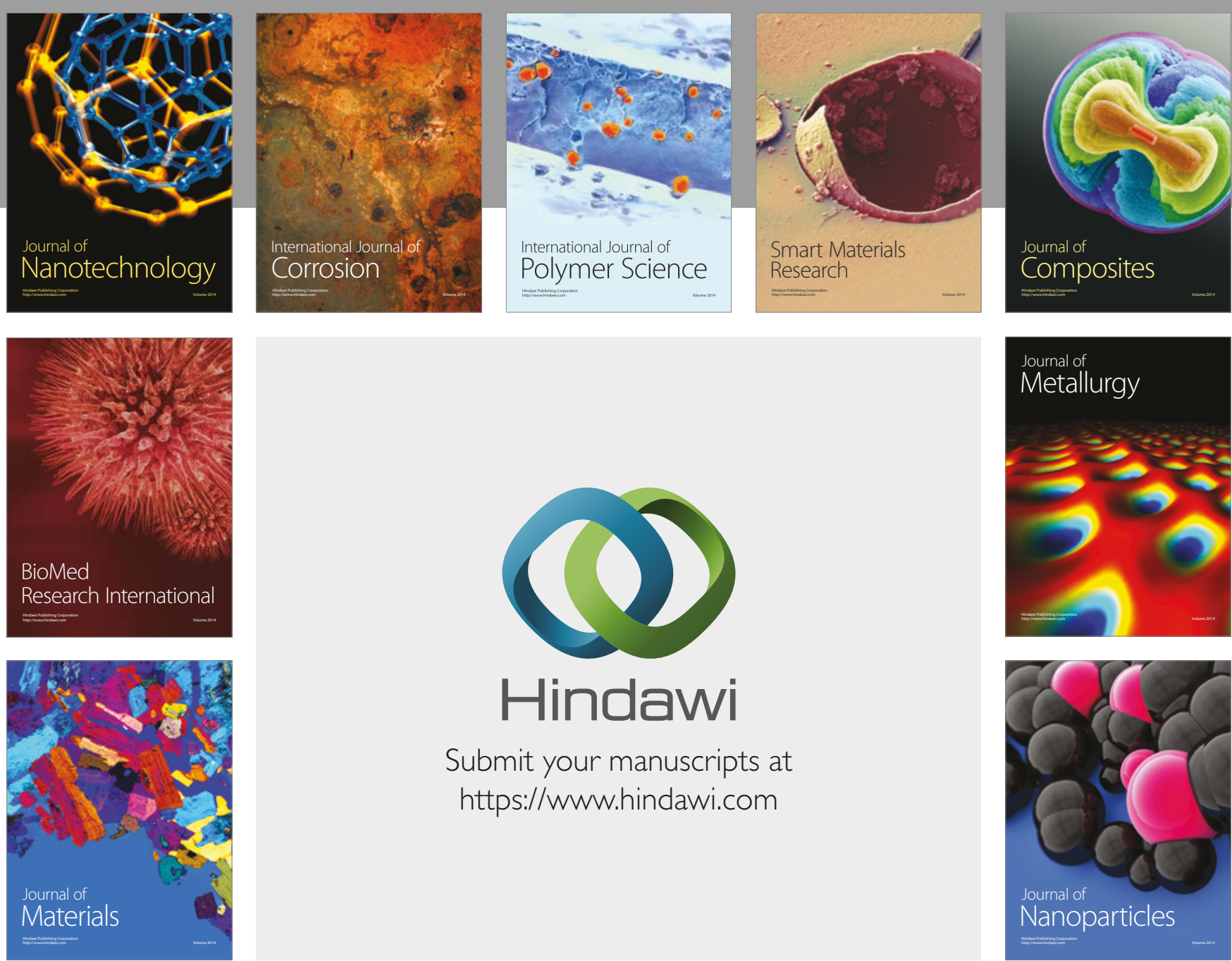

\section{Hindawi}

Submit your manuscripts at

https://www.hindawi.com
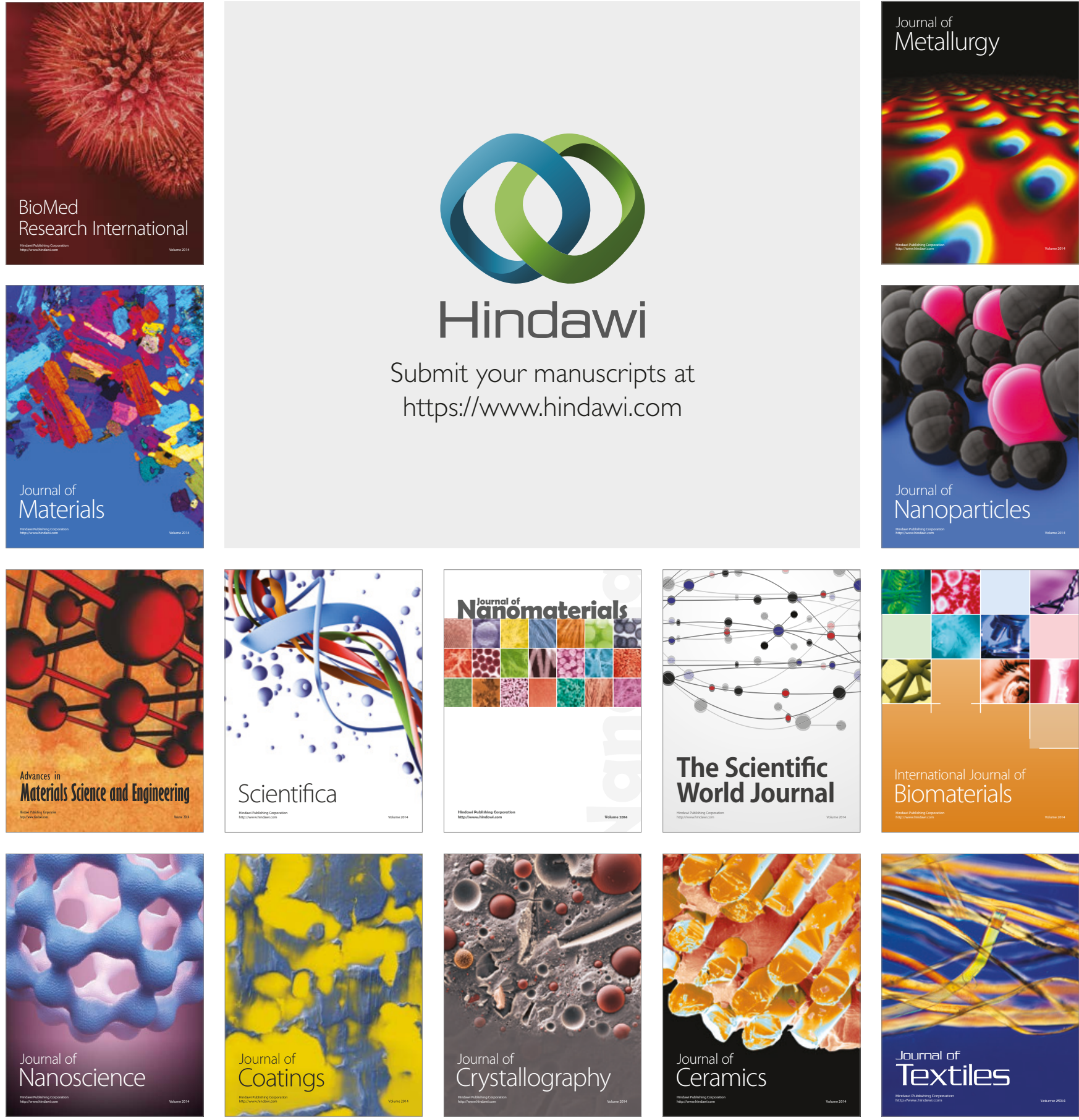

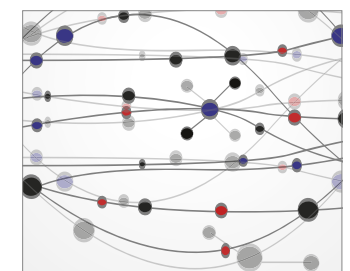

The Scientific World Journal
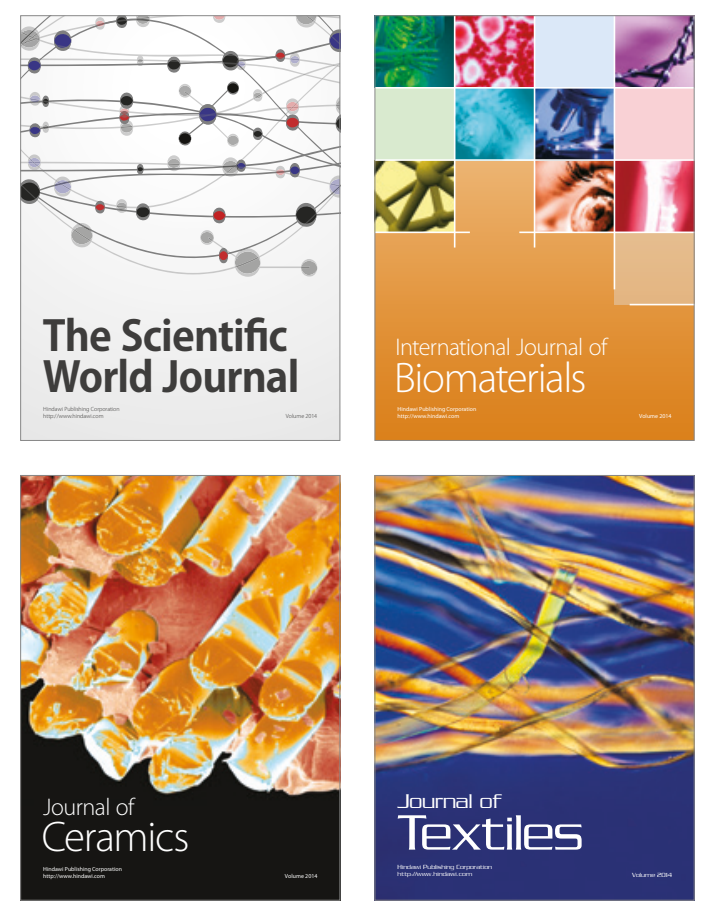